\title{
National small agribusiness policy in EAEU countries
}

\author{
Gennady Pratsko ${ }^{1,3^{*}}$, Tatyana Skvortsova ${ }^{2,3}$, Tatyana Epifanova ${ }^{2}$, and Yana Kurinova ${ }^{2}$ \\ ${ }^{1}$ Don State Technical University, Gagarin Square, 1, Rostov-on-Don, 344003, Russia \\ ${ }^{2}$ Rostov State University of Economics, B. Sadovaya str.,69, Rostov-on-Don, 344012, Russia \\ ${ }^{3}$ Rostov State Transport University, Rostovskogo Strelkovogo Polka Narodnogo Opolchenya Square, \\ 2, Rostov-on-Don, 344038, Russia
}

\begin{abstract}
The article is devoted to the study of national small and medium agribusinesses policy measures in the Eurasian Economic Union (EAEU) countries. To achieve the objectives of the study, the authors analyze the measures of state support for small and medium-sized businesses implemented in the EAEU member states as follows: the Russian Federation, the Republic of Belarus, the Republic of Armenia, the Republic of Kazakhstan, and the Republic of Kyrgyzstan. In the course of the study, the authors utilized the systemic and structural-functional methods of scientific development, the method of interpreting legal norms, as well as the logical method. Based on the results of the study, the authors concluded that it is necessary to consider the possibility of introducing new provisions into the EAEU Treaty, regarding the support of small and medium-sized businesses. A coordinated state policy to support small and medium-sized businesses on the territory of the single economic space of the EAEU could significantly affect the development of small and medium-sized businesses in the agricultural sector. In this regard, the proposed measures to support small and medium agribusiness are recognized as an incentive for the development of the agricultural market and the economy of the EAEU countries.
\end{abstract}

\section{Introduction}

In modern conditions, small and medium-sized businesses (SMEs) are becoming a priority area for the development of state policy for the long term in Russia and the EAEU countries. Small and medium-sized businesses and their clusters play a special role in the agricultural sector through ensuring the nationwide food security $[1,2]$. It is small and medium-sized enterprises that are able to establish efficient production of ecologically clean agricultural products [3]. However, despite the efforts of the authorities, an increase in the infusion of financial resources into this field of economy [4], the interest of government, a significant public outcry, the development of small business in Russia and the EAEU countries is accompanied by great difficulties. Within the framework of the EAEU, the state policy supporting the expansion of the agri-food market and the production

\footnotetext{
*Corresponding author: tas242@yandex.ru
} 
of competitive products are the factors for the successful integration and dynamic development of the agricultural sector.

The EAEU ensures the freedom of movement of goods, services, capital, and labor, as well as the implementation of a coordinated single policy in the economy sectors. However, within the framework of the EAEU, a unified policy is not provided for supporting small businesses, including the framework of agro-industrial production.

In industrialized countries, especially within the framework of the integration format, the development of the agri-food market and ensuring food security plays a leading role in the national security system. Increased competition in the production and sale of food and increased threats to food security determine different approaches to the regulation of agricultural production and support measures between individual countries. [5]

A support to the agro-industrial sector within the EAEU could be provided through effective incentives for agricultural producers, consumer support, regulation of the agrifood sector and the market.

Within the framework of the EAEU, the development and implementation of a single agricultural practice should be aimed at ensuring sustainable and balanced development of the agri-food market based on effective state regulation of the agro-industrial complex, and expanding integration processes.

Each EAEU country pursues an independent internal policy regarding government incentives for the development of small agribusiness; it requires harmonization of government support systems coupled with the formation of an effective support system for agribusiness, including SMEs [6].

\section{Methodology}

The study was carried out on the basis of traditional and approved methods of scientific research of economic and legal phenomena. The application of systemic and structuralfunctional methods was the basis for the analysis of EAEU countries' policies regarding the agribusiness. Consideration of some legal aspects of the topic under study was facilitated by the utilization of methods of interpretation of legal norms, as well as the logical method.

\section{Results}

\subsection{Development of agribusiness SMEs in the EAEU}

The Russian Federation has the lowest share of SMEs' contribution to the country's GDP among all EAEU countries. In 2018, this index was only $20.2 \%$, which is less than the same index for 2017 (22\%). In accordance with the National Project "Small and Medium Enterprises and Support for Individual Entrepreneurial Initiatives", the share of SMEs in GDP should reach $32.5 \%$ by 2024

The current regulatory framework of SMEs' activities dates back to 2007, to the adoption of the Federal Law No. 209-FZ "On the development of small and medium business in the Russian Federation" (the Federal Law on SMEs).

Since 2016, Russia has maintained a unified register of SMEs. The introduction of this accounting tool played a positive role and made possible simplifying the mechanisms for identifying business entities that are entitled to receive various types of state support established for SMEs. The statistical records of the number and various indicators of business activities of SMEs in Russia have been carried out since this period [7, 8].

The legislation of the Russian Federation provides for various forms of support for small and medium-sized businesses in Russia. In particular, the Federal Law on SMEs 
includes the following: "financial, including guarantee, property, information, consulting support of such entities and organizations, support in the field of training, retraining and advanced training of their employees, support in the field of innovation and industrial production, handicrafts, support for small and medium-sized businesses engaged in foreign economic activity, support for small and medium-sized businesses engaged in agricultural activities". These measures should contribute to the development of various business aspects [9-11].

Fig. 1 represents the number of SMEs in Russia since 2016.

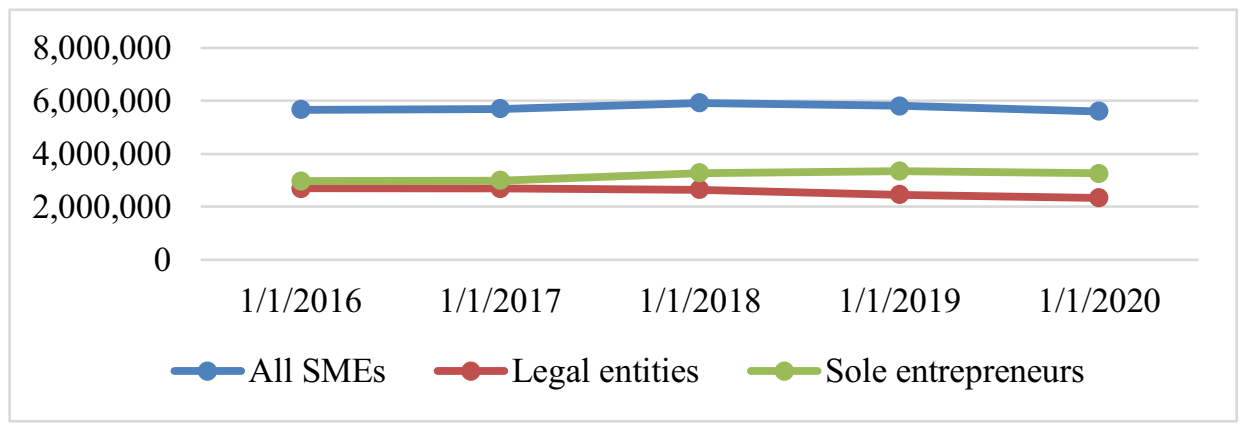

Fig. 1. The number of SMEs in Russia. Source: Compiled by the authors on the basis of Unified SMEs register: https://ofd.nalog.ru/statistics.html.

Based on the data in Fig. 1, we could sum up that the largest number of SMEs was recorded in 2018. Currently, there is a downward trend in the number of SMEs, which, in our opinion, is associated with the introduction of a high alert and self-isolation regime in March-June 2020 due to the COVID-19 threat. It is also necessary to highlight the upward trend in the number of sole entrepreneurs and a decrease in the number of legal entities in the structure of SMEs. Entrepreneurs prefer to carry out activities in a simpler form of organizing a small business - without forming a legal entity.

In the Republic of Belarus, the share of SMEs in the country's GDP is not large. According to data for 2019, it was 26.1\%. But unlike the Russian Federation, the share of SMEs in Belarus' GDP is growing (in 2018 the share amounted to 24.6\%). Thus, the importance of SMEs in the country's economy is growing, which indicates the effectiveness of the state policy in supporting SMEs.

The legal and organizational foundations for supporting SMEs, creating favorable conditions for its development are determined by the Law of the Republic of Belarus of 01 July 2010 No. 148-3 (as amended on 18.01.2018) "On support of small and medium-sized businesses" (the Law on SMEs in RB).

In accordance with Art. 1 of the Law on SMEs in RB, "the support for Small and Medium-Sized Businesses is the implementation by state bodies and other organizations of legal, economic, social, informational, consulting, educational, organizational and other measures to create favorable conditions for the development of small and medium-sized businesses and their infrastructure".

The key principles of state policy in supporting SMEs are:

- ensuring the equal opportunities for small and medium-sized businesses to receive support in accordance with legal background, transparency, and integrated approach of its provision;

- participation of representatives of SMEs, associations and unions of SMEs in the formation of state policy in the field of support for SMEs, development of draft regulations and standards of support for SMEs (p. 1, article 6 of the Law on SMEs in RB).

Fig. 2 represents the number of SMEs in RB since 2010. 


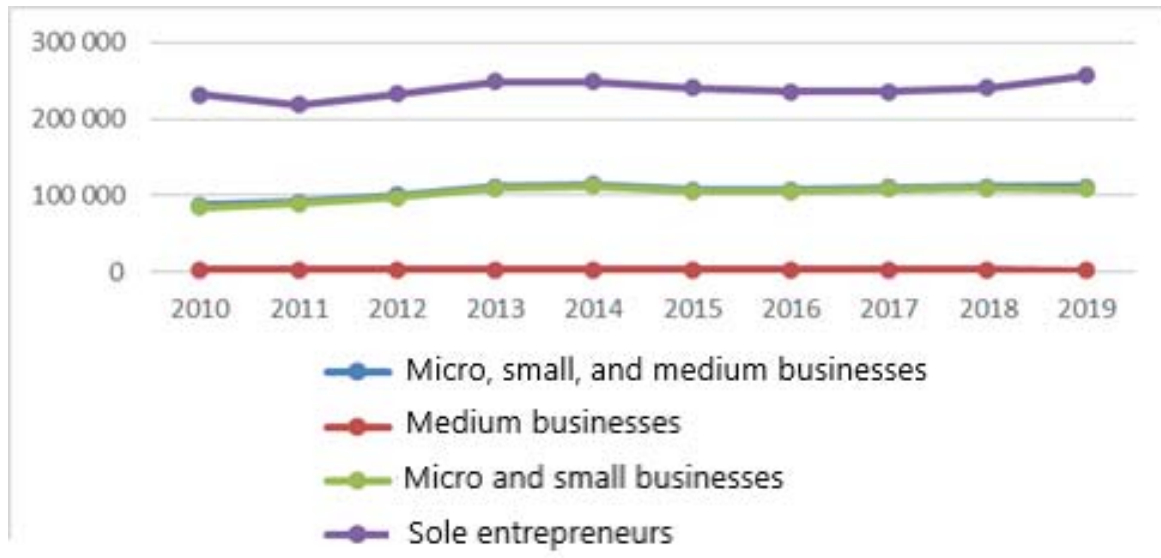

Fig. 2. The number of SMEs in RB. Source: Compiled by the authors on the basis of the official data provided by the National statistical committee of the RB: https://www.belstat.gov.by/.

The Fig. 2 shows that the number of SMEs (legal entities) is approximately two times less than the number of sole entrepreneurs. Thus, the legal framework of Belarus creates the most favorable and simplified conditions for business activities without incorporation.

Among legal entities, the overwhelming number of entities are small and microenterprises. Medium organizations have an insignificant share in the total number of legal entities of SMEs.

Small and medium business in the Republic of Kyrgyzstan have an important place in national economy. According to the National Statistical Committee of the Republic of Kyrgyzstan, for 6 months of 2020, the share of gross value added of SMEs in GDP (excluding companies engaged in 'Kumtor' exploitation) was $36.7 \%$. This is slightly less than in the same period in 2019 (37.6\%). The decrease in the indicator was caused by the fact that small and medium-sized businesses were most affected by the restrictions on business activities introduced in the first half of 2020 due to the COVID-19 pandemic. But despite the decrease, the share of gross value added by SMEs in the country's GDP is still one of the highest among the EAEU countries.

The regulation of relations to support small and medium-sized businesses in Kyrgyzstan is mostly determined by the key legal act in this area i.e., the Law of the Republic of Kyrgyzstan of 25 May 2007 No. 73 "On state support for small business" (the Law on SMEs in RK). According to Art. 3 of the Law on SMEs in KR, "small businesses are understood to be individuals engaged in entrepreneurial activities without incorporation, as well as commercial organizations and enterprises carrying out economic activities with a gross revenue not exceeding the registration threshold for value added tax per year, provided for The Tax Code of the Republic of Kyrgyzstan, and in which the average number of employees for the reporting period does not exceed the following maximum levels (small enterprises): in industry - 35 people; in construction - 75 people; on transport 35 people; in agriculture - 50 people; in the scientific and technical sphere -25 people; in the wholesale trade - 30 people; in retail trade and consumer services - 25 people; in other industries and in other types of activities - 25 people.

At the same time, the share of state, public and religious organizations (associations), charitable and other funds' interest in the authorized capital of small business entities should not exceed 10 percent. The share in the authorized capital of a small business entity owned by one or several legal entities that are not small business entities should not exceed 20 percent. 
A specific feature of the legal regulation in supporting small business in the Republic of Kyrgyzstan is the lack of division of small business into micro-enterprises and small enterprises, as is done by the laws of the Russian Federation and the Republic of Belarus. Small businesses are the only category highlighted.

State support for small businesses is carried out in the directions defined in Art. 6 of the Law on SMEs in RK.

State support for small and medium-sized businesses in the Republic of Kyrgyzstan is carried out within the framework of relevant government programs. Thus, the Development Program of the Republic of Kyrgyzstan for 2018-2022 is currently in force. "Unity, Trust, Creation", which has a section dedicated to the development of SMEs.

The Fig. 3 shows the dynamics of the number of SMEs in the Republic of Kyrgyzstan.

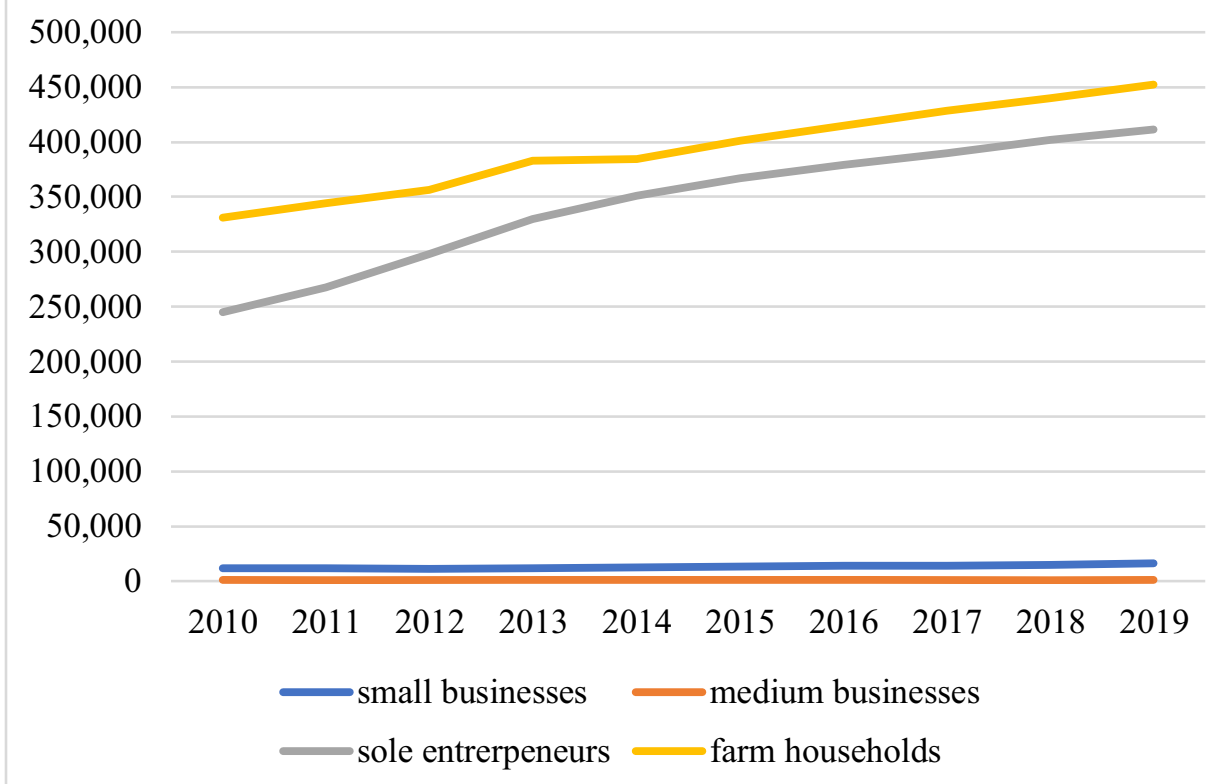

Fig. 3. The number of SMEs in RK. Source: Compiled by the authors on the basis of the official data provided by the National Statistics Committee of the RK: http:/www.stat.kg/ru/statistics/maloe-isrednee-predprinimatelstvo/.

Fig. 3 indicates a significant predominance of farm households (including individual entrepreneurs engaged in agricultural activities) and individual entrepreneurs in the structure of small and medium-sized businesses in Kyrgyzstan. The number of small and medium enterprises is much smaller. Thus, in Kyrgyzstan, there are predominantly entities engaged in entrepreneurial activities without incorporation, mainly in agriculture.

The dynamics of the number of small and medium-sized businesses in Kyrgyzstan shows a steady increase in the number of farm households and sole entrepreneurs (entities operating without incorporation). The number of small enterprises increased slightly from 2010 to 2019 , while the number of medium-sized enterprises decreased slightly from 2010 to 2019 .

In the Republic of Armenia, small and medium-sized business has a leading position in the economic field, it determines the economic indicators of the country's development, having a qualitative impact on GDP and a significant impact on the employment index [12].

The basic document of the socio-economic development of the Republic of Armenia is the Strategy for the Socio-Economic Development for 2014-2025 (the Strategy). It is a logical continuation of the Strategy for the Development of the SMEs for 2016-2018 and 
clearly reflects the EU's "growth strategy" named Europe 2020. The priority of the Strategy is the development of the private sector and SMEs, increasing their competitiveness, employment of the population, and the development of innovations in certain target priority industries like the food one and tourism. In these fields, Armenia has high growth potential according to marketing research.

The food industry is one of the most important sectors of the Armenian economy. The food industry in Armenia is quite diversified and includes almost all sectors from growing to processing grapes, fruits and vegetables, dairy products and tobacco. However, food processing capacity is insufficient. The food industry in Armenia faces constraints related to both domestic demand and export potential. The key factor holding back the domestic market is the quantity and quality of domestic supplies. The lack of structured holding chains is also a major obstacle to both markets, critical to improving product quality and meeting export quality standards to expand exports. For a few small suppliers, this is difficult to organize, provide the required quantity of the same quality, and requires an expensive traceability system. This increases the total cost of primary production. These factors have a direct impact on cost competitiveness. SMEs are poorly informed about the final markets. This leads to limited sales, limited market diversification, and impacts on product quality. At the same time, the existing production facilities in this sector have great potential for the development of small and medium-sized enterprises, leading to the development of the sector and an increase in production.

Tourism is one of the most dynamically developing industries of the Armenian economy. Armenia ranks 89 out of 141 countries in travel and tourism and has significant growth potential in sectors like ecology, adventure, winter tourism, culture, etc. Development of the tourism will contribute to the development of social and economic resilience of rural communities, provide stable income, provide employment for the population, and reduce migration from rural areas. The most promising for the development of the food industry and tourism are Armavir region, Lori region, Syunik region. As of the end of 2018, 75,000 small businesses were established in Armenia, accounting for 98\% of the total number of active businesses in Armenia. The main SMEs are concentrated in Yerevan (53\%), then in Armavir (7\%), Kotayk (7\%) and Lori (6\%), fewer SMEs work in Aragatsotn, Vayots Dzor and Tavush (2-3\%). The majority of SMEs (58.7\%) are employed in the wholesale and retail sector, with $97 \%$ share in the micro-business category. There are about 4,500 small and medium enterprises operating in Lori; about 5250 small businesses in Armavir; about 3750 in Syunik.

Successful sustainable development of small business in the agricultural sector is possible when joining the global value chain, improving product quality, successful branding and the concept of modern delivery [13-17].

In the regions of Armenia, we highlight a great potential for the development of the production of dried fruits (apricots, peaches, etc.), vegetables (tomato, eggplant, red pepper), and in Syunik, due to weather conditions, there is a potential for the development of processing of subtropical fruits and berries.

In the Republic of Armenia, as well as in Russia, all-round support is provided to small businesses, aimed at increasing their activity, export potential and competitiveness.

In 2000, the Law of the Republic of Armenia of 28 December 2000 No. ZR-121 "On State Support for Small and Medium Enterprises" was adopted, which consolidated the criteria for differentiating business entities into categories for the effective distribution of state support. The established criteria generally correspond to the criteria for SMEs adopted in Russia and in most of the EU countries.

We consider the level of development of small business and the state support provided in the Republic of Kazakhstan. There, entrepreneurial relations are regulated by the Entrepreneurial Code (EC RK), which distinguishes the following categories of 
entrepreneurial structures: medium, large, small business and microentrepreneurship. This division takes place solely by the number of employees of the enterprise and for obtaining support based on two criteria: the average annual number of employees and the average annual income.

Small business could be carried out in the form of personal entrepreneurship and joint entrepreneurship. Joint venture is understood as 1) spouses' entrepreneurship carried out on the basis of common joint property of spouses; 2) family entrepreneurship carried out on the basis of common joint ownership of a farm household or common joint ownership of a privatized dwelling; 3) a simple partnership, in which private entrepreneurship is carried out on the basis of common shared ownership; 4) other forms in accordance with the laws of the Republic of Kazakhstan. (Article 32, clause 3 of the EC RK).

Entrepreneurs have the right to use the system of social and pension security, social insurance in accordance with the legislation of the Republic of Kazakhstan.

At the same time, entrepreneurs who meet the criteria of small business, but carry out certain types of activities, could not be recognized as small businesses. These types of activities include the following: activities related to transactions in the circulation of narcotic drugs, psychotropic drugs, precursors; production activity or wholesale trade in excisable goods or excisable products; activities related to the storage of grain; activities related to the conduct of lotteries and the organization of the gambling business; activities for the circulation of radioactive components; financial and banking activities and activities in the financial services market; auditor's activities; activities of participants in the securities market; activities of loan offices; security activities, etc.

The EC RK guarantees equality of business entities, inviolability of property, freedom of entrepreneurship and fair competition.

Art. 14 of the EC RK provides for the mutual responsibility of business entities and the state, it is stipulated that in the process of state regulation of entrepreneurship, obstacles should not be created to the implementation of the legal activities of business entities by state bodies and their officials. In turn, entrepreneurs are also obliged to act in good faith.

Art. 15 of the EC RK establishes freedom from corruption. In the implementation of state regulation of entrepreneurship, facts of conflict of interest and selective application of law should be excluded, as well as to limit contacts between state bodies and entrepreneurs, the principle of "one window" is provided, in which all the necessary approvals from state bodies must be obtained by the state bodies in the order of interdepartmental interaction. Illegal interference of the state in business entities' activity and their associations is not allowed. Participation of entrepreneurship entities in rule-making is envisaged, namely, the participation in the development and examination of draft regulatory acts, draft international treaties of the Republic of Kazakhstan, as well as international treaties to which the Republic of Kazakhstan intends to become a party, affecting the interests of entrepreneurship entities, through the National Chamber of Entrepreneurs of the Republic of Kazakhstan and expert council on private entrepreneurship. (Article 19).

Entrepreneurs have the right, in order to protect their interests, not to admit officials to the inspection if they violate the provisions of the EC RK, and may also involve third parties to participate in the inspection.

State support for private entrepreneurship in Kazakhstan is provided in the following key areas: 1) small and medium business; 2) agro-industrial complex and non-agricultural types of entrepreneurial activity in rural areas; 3) industrial and innovative activity; 4) special economic zones; 5) industrial zones; 6) investment activities; 7) entrepreneurship of domestic producers of goods; 8) housing construction. (Article 92 of the EC RK).

The key types of support in Kazakhstan are financial and property support; infrastructural support; institutional support, which includes the creation of financial institutions for the support and development of private entrepreneurship, research institutes 
under state bodies to study problems and develop proposals for private entrepreneurs and their informational support including analytical, educational, methodological, and scientific support of private entrepreneurship.

The development of small business in the Republic of Kazakhstan is an important economic objective and a factor in diversifying the economy. As of June 1 of 2020, 1,3 million small and medium-sized businesses were operating in the country. At the beginning of 2020, the share of small and medium-sized businesses in the economy of the Republic of Kazakhstan amounted to $30.8 \%$, and the volume of manufactured goods reached 31.2 trillion tenge. The COVID-19 outbreak had a negative impact on the activities of SMEs. In these conditions, support for SMEs becomes an increasingly important concern: due to the recession in economic activity, the government's priority task is to restore lending to the economy and promote the access to credit resources. In the Republic of Kazakhstan, as in Russia, the main financial support for SMEs is provided by microfinance organizations.

In addition to financial support, the state provides SMEs with tax incentives, so since January 1, 2020, micro and small businesses applying special tax regimes are exempt from income taxes for three years.

Let us analyze the contribution of small agricultural enterprises to the EAEU economy in the total volume of goods produced for the period 2017-2019.

Table 1. The share of agricultural producers in the total volume of goods produced by small businesses (including microenterprises) in the Russian Federation.

\begin{tabular}{|c|c|c|c|}
\hline Russia, million rubles & 2017 & 2018 & 2019 \\
\hline $\begin{array}{l}\text { Total for the types of economic } \\
\text { activities under study }\end{array}$ & 20134891335 & 21292779953 & 21996292770 \\
\hline $\begin{array}{l}\text { agriculture, forestry, hunting, fishing } \\
\text { and fish farming }\end{array}$ & 796240412 & 904113444 & 920182363 \\
\hline $\begin{array}{l}\text { The share of agricultural products in } \\
\text { the total volume of production }\end{array}$ & $3,95 \%$ & $4,24 \%$ & $4,18 \%$ \\
\hline Kazakhstan, million tenge & 2017 & 2018 & 2019 \\
\hline $\begin{array}{l}\text { Total for the types of economic } \\
\text { activities under study }\end{array}$ & 23241125 & 26473049 & 32386960 \\
\hline $\begin{array}{l}\text { agriculture, forestry, hunting, fishing } \\
\text { and fish farming }\end{array}$ & 1822652 & 2057209 & 2510170 \\
\hline $\begin{array}{l}\text { The share of agricultural products in } \\
\text { the total volume of production }\end{array}$ & $7,84 \%$ & $7,77 \%$ & $7,75 \%$ \\
\hline Kyrgyzstan, million soms & 2017 & 2018 & 2019 \\
\hline $\begin{array}{l}\text { Total for the types of economic } \\
\text { activities under study }\end{array}$ & 118035,2 & 124426,3 & 147892,5 \\
\hline $\begin{array}{l}\text { agriculture, forestry, hunting, fishing } \\
\text { and fish farming }\end{array}$ & 2512,6 & 2533,4 & 2927,9 \\
\hline $\begin{array}{l}\text { The share of agricultural products in } \\
\text { the total volume of production }\end{array}$ & $2,12 \%$ & $2,03 \%$ & $1,97 \%$ \\
\hline Armenia, million drams & 2017 & 2018 & 2019 \\
\hline $\begin{array}{l}\text { Total for the types of economic } \\
\text { activities under study }\end{array}$ & - & - & 7111255,1 \\
\hline $\begin{array}{l}\text { agriculture, forestry, hunting, fishing } \\
\text { and fish farming }\end{array}$ & - & - & 1330565,4 \\
\hline $\begin{array}{l}\text { The share of agricultural products in } \\
\text { the total volume of production }\end{array}$ & - & - & $18,71 \%$ \\
\hline Belarus, million rubles & 2017 & 2018 & 2019 \\
\hline $\begin{array}{l}\text { Total for the types of economic } \\
\text { activities under study }\end{array}$ & 122705 & 147488,3 & 155854 \\
\hline $\begin{array}{l}\text { agriculture, forestry, hunting, fishing } \\
\text { and fish farming }\end{array}$ & 18043 & 18843 & 20639 \\
\hline $\begin{array}{l}\text { The share of agricultural products in } \\
\text { the total volume of production }\end{array}$ & $14,7 \%$ & $12,77 \%$ & $13,24 \%$ \\
\hline
\end{tabular}


Armenia has the largest share in the total revenue of SMEs in the field of agricultural products in 2019, the share in the revenue of agricultural enterprises was $18.71 \%$, followed by the Republic of Belarus - $13.24 \%$ in 2019 , which is $1.5 \%$ less than in 2017 , in third place is Kazakhstan $-7.75 \%$ in 2019 , in fifth place is the Russian Federation $-4.18 \%$ in 2019 and Kyrgyzstan ends $-1.97 \%$ in 2019. In our opinion, all the EAEU countries have growth potential, with a competent strategy for distributing support to agricultural producers.

\section{Conclusion/recommendations}

For the EAEU countries, the SME sector is one of the priority areas of economic policy. The analysis of state policy in various states allows presenting data on the development of small and medium-sized enterprises in the EAEU countries and their share in GDP in Table 2 in dynamics over the past three years.

Table 2. Dynamics of small business development in the EAEU in 2017-2019.

\begin{tabular}{|c|c|c|c|c|c|c|}
\hline $\begin{array}{c}\text { EAEU } \\
\text { member state }\end{array}$ & $\begin{array}{c}\text { Number of } \\
\text { SMEs in } \\
2017\end{array}$ & $\begin{array}{c}\text { Share of } \\
\text { SMEs in } \\
\text { GDP in } \\
2017\end{array}$ & $\begin{array}{c}\text { Number of } \\
\text { SMEs in } \\
2018\end{array}$ & $\begin{array}{c}\text { Share of } \\
\text { SMEs in } \\
\text { GDP in } \\
2018\end{array}$ & $\begin{array}{c}\text { Number of } \\
\text { SMEs in } \\
2019\end{array}$ & $\begin{array}{c}\text { Share of } \\
\text { SMEs } \\
\text { in GDP } \\
\text { in } 2019\end{array}$ \\
\hline Russia & 5695609 & $22,3 \%$ & 6042898 & $20,2 \%$ & 5924681 & $22,9 \%$ \\
\hline Belarus & 456080 & $24,7 \%$ & 457180 & $24,6 \%$ & 478554 & $26,1 \%$ \\
\hline Kyrgyzstan & 833161 & $39,3 \%$ & 856549 & $38,2 \%$ & 880691 & $39 \%$ \\
\hline Armenia & 59575 & $34,4 \%$ & $\mathrm{n} / \mathrm{a}$ & $26 \%$ & 68500 & $26 \%$ \\
\hline Kazakhstan & 1146000 & $25,6 \%$ & 1166900 & $27 \%$ & 1288300 & $28 \%$ \\
\hline
\end{tabular}

In all EAEU countries, except for Russia, a steady growth trend in the number of SMEs was formed over the period $2017-2019$. However, the COVID-19 crisis is likely to change the growth trend to negative.

Almost all countries have revised and updated the Strategy for the Development of Small and Medium Enterprises for the period after 2020 in order to mitigate the effects of the coronavirus pandemic. Particular attention is paid to improving bankruptcy procedures, overcoming difficulties in accessing funds and the need to involve SMEs in large value chains.

Progress is visible in improving the business climate, especially with regard to information and consulting activities. However, similar barriers remain for small and medium-sized businesses, primarily in accessing funds, as well as administrative and taxation issues. The EAEU Treaty does not contain a separate chapter that would concern small and medium-sized businesses. Due to the growing interest in the issue of SMEs in the world and in all EAEU countries, the possibility of introducing new provisions in the Treaty should be considered. To combine efforts in the development of SMEs, including for the formation of an efficient economy, growth of employment, welfare and stability of society, the development of common markets in the EAEU, a special department should be created within the Department for the Development of Entrepreneurship of the Eurasian Economic Commission, which is responsible for the development of SMEs in the EAEU. It is advisable to create a unified electronic portal of the EAEU, which collects information on measures to support SMEs and regulation rules in the EAEU countries with links to relevant websites, as well as on how small and medium-sized businesses could utilize the benefits of the EAEU. In order to promote a positive business image of the EAEU, it is 
necessary to promote the concept of "goods of the Eurasian Economic Union" concept to form union brands of individual goods.

Within the EAEU, it is necessary to develop a unified agrarian strategy aimed at ensuring sustainable and balanced development of the agri-food market based on effective state regulation of the agro-industrial complex, and expanding integration processes. An important strategy mechanism should be the improvement of the mechanism for lending to agricultural enterprises, especially small and medium-sized businesses. This problem could be solved by creating a specialized bank or credit organization within the EAEU.

One of the key principles for implementing the strategy for supporting agro-industrial enterprises is the development and implementation of uniform food safety standards, as well as the creation of an ecosystem of agricultural producers, taking into account natural and climatic conditions to prevent competition within the system and create a powerful export base for agricultural products through specialization of production. The development of a unified logistics system for the sale of products in the domestic and foreign markets will create an effective mechanism for delivering products to the end consumer and will reduce the costs associated with transportation. The creation of hubs for the sale of agricultural products will allow small producers entering foreign markets with their products. In the context of state regulation of the agro-industrial complex of the EAEU countries, it is necessary to unify the forms and methods of state regulation and support of the agrarian sector of the economy, create systems for modeling and forecasting the development of the agri-food sector within the framework of the world economy. For the effective use of financial resources in the EAEU countries, it is advisable to establish standards for the formation and optimization of the banking system. It is necessary to introduce a unified insurance program for agricultural producers within the EAEU. This will contribute to the protection of agricultural producers from unforeseen losses arising in case of emergencies (natural, epidemiological, etc.). It is also necessary to harmonize the tax system in relation to agricultural producers, introduce a single agricultural tax for peasants and farms, providing for exemption from all types of taxes, replacing them with a single land tax, a calculation base, which includes the area of the land plot multiplied by the estimated cost with the rate not exceeding $5 \%$.

An unified and integrated approach to state support for the agricultural sector of the economy will ensure equal conditions for agricultural producers in the EAEU countries, increase the productivity of the agro-industrial complex, and its competitiveness in foreign markets.

\section{References}

1. E. Popkova, T. Litvinova, N. Saveleva, et al., European Research Studies Journal, 18(3), 177-186 (2015)

2. O. Borisova, L. Abramova, L. Zageeva, et al., European Research Studies Journal, 18(3), 287-298 (2015)

3. T.A. Skvortsova, N.G. Shatveryan, O.V. Alimova, Advances in Economics, Business and Management Research, 147, 333-337 (2020), doi: https://doi.org/10.2991/aebmr.k.200729.063

4. T.A. Skvortsova, I.P. Denisova, N.G. Romanenko, A.V. Sukhovenko, European Research Studies Journal, 21(1), 423-431 (2018)

5. T.A. Taipov, Bulletin of the Karaganda State University (2018), https://articlekz.com/en/article/29348

6. N.G. Vovchenko, L.V. Sakharova, T.V. Epifanova, V.S. Kokhanova, Advances in Intelligent Systems and Computing, ISSN: 2194-5357, DOI: 10.1007/978-3-030- 
35249-3_35.

7. T.A. Skvortsova, A.A. Nikitina, T.A. Pasikova, A.V. Tagaev, IJEBA, 7(1), 417-425 (2019)

8. T.A. Skvortsova, T.A. Mosienko, N.G. Romanenko, Y.A. Kolesnikov, European Research Studies Journal, 20(3B), 369-378 (2017)

9. T.V. Epifanova. N.G. Romanenko, T.A. Mosienko, et al., European Research Studies Journal, 18(3), 137-148 (2015)

10. A.S.Mikhaylov, Entrepreneurship and Sustainability Issues, 5(4), 1020-1030 (2018), DOI: $10.9770 /$ jesi.2018.5.4(22)

11. Yu. A. Kolesnikov, T.V. Epifanova, A.M. Usenko, V.N. Ostrovskaya, Contemporary Economics, 10(4), 343-352 (2016), DOI: 10.5709/CE.1897-9254.221.

12. World Bank. 2020. Global Economic Prospects, June 2020 (World Bank, Washington, DC, 2020)

13. M. Zastempowski, N. Przybylska, Journal of Competitiveness, 8(2), 42-58 (2016), DOI: 10.7441 joc.2016.02.04

14. M.A. Lopez-Cabarcos, J. Pineiro-Chousa, L. Quinoa-Pineiro, Economic ResearchEkonomska Istrazivanja (2020), DOI: 10.1080/1331677x.2020.1838314

15. A.J. Fernandes, J.J. Ferreira, Review Of Managerial Science (2021), DOI: $10.1007 / \mathrm{s} 11846-020-00437-6$

16. E. Popkova, Applied Econometrics and International Development, 14(1), 5-25 (2014)

17. T.V. Shatkovskaya, A.A. Solonchenko, Ya.A. Emirsultanov, Yu.A. Naumenko, European Research Studies Journal, 20(3B), 432-442 (2017) 